УДК [37.091.33:004]:37.011.3-052-056.26

\author{
Щерба Наталія Сергіївна \\ кандидат педагогічних наук, доцент, \\ доцент кафедри міжкультурної комунікації та прикладної лінгвістики \\ Житомирський державний університет імені Івана Франка, м. Житомир, Україна \\ ORCID ID 0000-0002-5467-4292 \\ scherbanatasha@gmail.com
}

\title{
ВИКОРИСТАННЯ ЕЛЕКТРОННИХ ЗАСТОСУНКІВ У НАВЧАННІ ІНОЗЕМНОЇ МОВИ СТАРШОКЛАСНИКІВ 3 ДИТЯЧИМ ЦЕРЕБРАЛЬНИМ ПАРАЛІЧЕМ
}

\begin{abstract}
Анотація. Стаття присвячена актуальній проблемі підвищення ефективності навчання іноземної мови старшокласників із дитячим церебральним паралічем за рахунок відбору та систематизації електронних застосунків.

Згідно з Законом України «Про загальну середню освіту» учні з особливими освітніми потребами можуть навчатись у загальноосвітніх школах (зокрема в спеціальних / інклюзивних класах або за дистанційною / вечірньою / заочною формою навчання), а також у спеціальних школах (для дітей, що потребують корекції фізичного та / або розумового розвитку), до яких належать і навчально-реабілітаційні центри (для дітей, яким потрібна систематична реабілітація внаслідок складних порушень розвитку). Запровадження Соціальної моделі інвалідності, що розпочалося в Україні, передбачає поступову відмову від сегрегації дітей з інвалідністю в межах спеціальних навчальних закладів. Це означає максимальну компенсацію їхніх обмежень в інклюзивному навчальному процесі за рахунок його адаптації (чи, в меншості випадків, модифікації) до їхніх особливих освітніх потреб. Певний потенціал у цьому контексті мають електронні застосунки, які розглядаються у статті як користувацькі комп'ютерні програми, які дають змогу вирішувати конкретні прикладні задачі.

Переслідуючи мету статті, автор класифікує електронні застосунки за критеріями: місця їхнього функціонування (на ті, що знаходяться в Інтернеті на спеціально створених вебплатформах і не потребують завантаження на ПК, та ті, що вимагають завантаження); сфери застосування (на застосунки загального та спеціального призначення). Застосунки спеціального призначення, що можуть використовуватися в іншомовній освіті, пропонується класифікувати за компетентностями, для розвитку яких вони можуть використовуватись (тобто мовних, а також рецептивних і продуктивних мовленнєвих компетентностей).Систематизовані таким чином застосунки було відібрано у відповідності до особливих освітніх потреб старшокласників 3 дитячим церебральним паралічем. Отримані результати дослідження узагальнено у вигляді таблиць.
\end{abstract}

Ключові слова: іноземна мова; старшокласники; ДЦП; електронний застосунок.

\section{1.ВСТУП}

Постановка проблеми. Навчання іноземної мови (IM) учнів 3 особливими освітніми потребами має в Україні ряд невирішених навчально-організаційних питань, пов'язаних із переходом суспільства від Медичної моделі інвалідності до Соціальної і, як наслідок, пошуком оптимальних стратегій запровадження інклюзії.

Медична модель передбачає ізоляцію людей з обмеженими можливостями від суспільства, тобто їх сегрегацію в межах особливих установ, де вони могли б працювати, спілкуватися та отримувати різноманітні послуги на доступному їм рівні. Ця модель вважалася доцільною в минулому, проте сьогодні вона суперечить усім міжнародним документам, що обстоюють права людини [1]. Як вказано в матеріалах Саламанкської декларації, занадто довго суспільство концентрувало увагу на недоліках 
людей з обмеженими можливостями, а не на потенційних можливостях цієї категорії осіб. У документі рекомендовано змінити існуючу суспільну модель на більш гуманну, що забезпечила б дотримання прав людини [2, с. 6].

У свою чергу, Соціальна модель (модель "єдиного суспільства" [3]) передбачає:

- активізацію участі людей з особливими потребами в суспільному житті за рахунок створення необхідних умов (пандусів і спеціальних підйомників для осіб із обмеженнями в пересуванні, дублювання текстової інформації за допомогою абетки Брайля для сліпих і звукової інформації мовою жестів - для глухих тощо);

- підтримку державою заходів, що сприяють ефективній освіті та працевлаштуванню людей 3 особливими потребами у звичайні заклади й організації, у такий спосіб надаючи їм можливість самостійно забезпечувати своє існування;

- поліпшення ставлення суспільства до людей з особливими потребами як до співгромадян, що заслуговують на повагу та гідне життя [1].

Отже, передумовою запровадження Соціальної моделі $є$ реалізація державою таких комплексних завдань:

1. Адаптація суспільства до особливостей і потреб людей з інвалідністю.

2. Всебічна підготовка людей 3 обмеженими можливостями до активної життєдіяльності з метою їх максимальної соціальної інклюзії, спираючись на розвиток наявного в них компенсаторного потенціалу.

Згідно з матеріалами Сандберзької декларації, виконання вказаних вище завдань можливе за умови заохочення досліджень, спрямованих на пристосування сучасної технології до потреб школярів з особливими потребами та поширення одержаних результатів з метою освіти, культурного розвитку та забезпечення їх майбутньої зайнятості [4]. Вказані рекомендації стосуються учнів з усіма захворюваннями, що призвели до інвалідності, та, відповідно, вивчення всіх шкільних предметів. Тому дослідження електронних застосунків, які можуть полегшити навчання іноземних мов старшокласників з дитячим церебральним паралічем (ДЦП), є доцільним.

Аналіз останніх досліджень і публікацій. Проблематика використання інформаційно-комунікаиійних технологій (IKT) у навчальному прочесі висвітлена в роботах І.О. Беха, В.І. Волгова, Н.Д. Гальскової, Р.С. Гінзбурга, В.М. Загвязинського, Н.К. Каратова, А.В. Конишевої, О.І. Медвєдєвої, Н.В. Морзе, І.П. Воротникової, М. Фенчуна, І.О. Яковлєва та інших. Доцільність та особливості запровадження IKT у навчання іноземних мов було обгрунтовано у працях I.О. Беха, В.О. Бикова, О.В. Бурлака, В.І. Волгова, Р.С. Гуревича, В. Загвязинського, Л.А. Карташової, М.В. Лисенка, Н.В. Морзе, І.В. Пліш, З.В. Савченко та інших. Використання IКТ в освіті осіб з особливими потребами вивчалося такими вченими,як О.О. Ащаулов, О.М. Василенко, С.В. Геделевич, В.В. Дабіжа, С. Ебботт, А.М. Желудкова, К.І. Захарченко, С.М. Кирильчук, О. Легкий, С.С. Нестеренко, М. Норт, Л.А. Тарсукова, Л. Флоріан, Дж. Хегартіта ін.. Проте в ході проведеного аналізу наукових джерел не було виявлено публікацій, у яких би систематизувались електронні застосунки, що можуть використовуватись у навчанні ІМ старшокласників з ДЦП.

Мета статті полягає в систематизації тих електронних застосунків, що можуть використовуватись у навчанні IM старшокласників з ДЦП згідно з їх обмеженнями та відповідними особливими освітніми потребами. 


\section{2. РЕЗУЛЬТАТИ ДОСЛІДЖЕННЯ}

Доцільність використання ІКТ в іншомовній освіті учнів 3 інвалідністю $\epsilon$ очевидною, вона обгрунтована в Державному стандарті базової і повної загальної середньої освіти та в інших чинних нормативних документах. Проте вибір конкретних технологій залежить від ряду факторів.До них належать:

1) Форма навчання.

Відповідно до Статей 8-9 Закону України "Про загальну середню освіту" учні 3 інвалідністю (зокрема з ДЦП) можуть навчатися в:

- загальноосвітніх школах (зокрема в спеціальних / інклюзивних класах або за дистанційною / вечірньою (заочною) формою навчання);

- спеціальних школах (для дітей, що потребують корекції фізичного та / або розумового розвитку), до яких належать і навчально-реабілітаційні центри (для дітей, яким потрібна систематична реабілітація внаслідок складних порушень розвитку) [5].

Неможливість деяких школярів відвідувати заняття в школі (наприклад, у зв'язку 3 вибором дистанційної, заочної чи індивідуальної форми освіти) виправдовує доцільність використання школою віртуальних навчальних середовищ, які дозволяють учням більш самостійно досягати цілей навчального процесу. I навпаки, робота в класі (інклюзивному чи спеціальному) уможливлює запровадження такого електронного обладнання, як інтерактивні дошки SMART Boards 3 відповідним програмним забезпеченням або персональні комп'ютери, якими можна керувати за допомогою приладу Tobii Dynavox eye tracker, що відстежує рухи очей і дозволяє відкривати й закривати вікна, вивчаючи відповідну інформацію. Це актуально для учнів, що неспроможні писати чи друкувати. Вказані прилади є дороговартісними, тому вони, як правило, не купуються для індивідуального користування.

Форми навчання впливають і на вибір електронних застосунків у тому сенсі, чи стосуються вони більшою мірою навчальної чи корекційної роботи. Специфіка перебування дітей у спецшколах передбачає організацію останньої на регулярній основі (особливо в навчально-реабілітаційних центрах).У випадку з учнями з ДЦП до відповідних технологій належать, наприклад:

- крокові реабілітаиійні ігри, що реалізуються за допомогою т. зв. танцювального мату (Dance Mat) i відповідного програмного забезпечення.Це допомагає вдосконалити крокові рухи, рівновагу, швидкість рухової реакції та когнітивні здібності дитини;

- прилади для тренування рівноваги, як-от: балансувальна дошка Nintendo Wii Fit та відповідне програмне забезпечення (ігри);

- прилади для розвитку функиії кисті (кистеві маніпулятори та відповідні комп'ютерні ігри);

- прилади для тренування рухових функцій у дітей з незначною затримкою моторного розвитку із застосуванням ігрових приставок Nintendo Wii та Xbox iз сенсором рухів Kinect, а також програмного забезпечення, що дозволяє розвивати рухливість та швидкість реакцій кінцівок чи всього тіла [7].

Електронні застосунки, що стосуються навчальної роботи, будуть розглянуті далі.

2) Предмет, щуо вивчається.

У залежності від специфіки шкільних предметів учителі можуть запроваджувати ті чи інші електронні застосунки, що дозволяє ефективніше реалізувати завдання уроку.

Поняття «електронний застосунок» (також «електронний додаток», «прикладна 
програма», «застосування», «веб-застосунок») тлумачиться як «користувацька комп'ютерна програма, що дає змогу вирішувати конкретні прикладні задачі користувача» [6]. Застосунки можуть використовуватись на комп'ютері, мобільному пристрої чи планшеті. За критерієм розміщення їх можна розподілити на:

- ті, що розміщені в Інтернеті на спеціально створеній веб-платформі і не потребують завантаження на ПК (наприклад, PlayPosit);

- ті, що не розміщені на веб-платформі та вимагають завантаження на ПК, планшет чи мобільний пристрій (як-от: Anki).

- 3 позиції сфери застосування вони умовно розподіляються на:

- застосунки загального призначення, що застосовуються користувачами різних категорій (текстові редактори: Word, Lexicon; графічні редактори: Paint, Adobe Photoshop; табличні процесори:Excel, QuattroPro, Works тощо).

- застосунки спеціального призначення, що виконують функції, корисні для більш специфічних видів людської діяльності, наприклад, для навчання іноземної мови(Anki, PlayPosit, Voxopop, LessonPath (Mentormob) та інші).

У межах середньої іншомовної освіти застосунки можна умовно класифікувати за компетентностями, для розвитку яких вони можуть використовуватись:

а) застосунки, спрямовані на розвиток мовних компетентностей:

- фонологічної (Voxopop, Accent School);

- лексичної (VocApps, Anki);

- граматичної (LearningApps, English Grammar in Use Activities);

б) застосунки, спрямовані на розвиток рецептивних мовленнєвих компетентностей:

- читання (Lino, Lessonpaths / Mentormob);

- аудіювання (PlayPosit, Audacity);

- застосунки, щзо сприяють розвитку продуктивних видів мовлення:

- усного мовлення: монологічного (MyTours, DotSub) та діалогічного (Scratch, HelloTalk);

- писемного мовлення (WordPress, PBWorksWiki) тощо.

Запропонований перелік застосунків $є$ корисним для організації іншомовної освіти учнів 3 типовим розвитком. Проте в навчанні старшокласників з ДЦП виникає потреба в подальшій систематизації та відборі електронних застосунків із позиції обмежень і відповідних особливих освітніх потреб учнів, що проявляються у вивченні IM. Розглянемо останні детальніше.

Термін "дитячий церебральний параліч" походить від лат. "cerebrum" - "мозок" та від грецьк. "paralysis" - "розслаблення" і описує групу найскладніших, пожиттєво інвалідизуючих захворювань у дітей, викликаних патологією центральної нервової системи [8, с. 49]. Термін описує порушення розвитку рухів і положень тіла, що зумовлюють обмеження активності та спричинені непрогресуючим ураженням мозку плода чи дитини в період раннього розвитку [8, с. 184]. Захворювання проявляється в порушеннях не лише моторних, але й когнітивних і комунікативних функцій, чутливості, перцепції, поведінки дитини, а також у судомних розладах [8, с. 184]. За комплексом таких порушень, їх характером i ступенем важкості в кожному конкретному випадку встановлюється форма захворювання.

Питаннями класифікації форм ДЦП займалися такі науковці, як Дж. Казаувієлх, У.Дж. Літтл, 3. Фрейд, Дж. Ентон, А.І. Бетем, О. Фостер, У. Фелбс, Ф. Форд, К. Бобат і Б. Бобат та ін. Однак, на думку Л.О. Бадаляна, Л.Т. Журби та О.В. Тімоніної [9], досконала класифікація досі не була укладена, оскільки цьому перешкоджає різноманіття факторів, що викликають ураження мозку, відсутність специфіки 
відповідних реакцій; порушення взаємозв'язків функціональних систем у процесі їх розвитку тощо. Як внесок у вирішення цієї проблеми, автори пропонують класифікувати форми ДЦП за віком хворих, враховуючи відповідні змішані форми.

Отже,для дітей шкільного віку характерні наступні форми:

1. Спастичні: а) диплегія; б) геміплегія; в) подвійна геміплегія.

2. Гіперкінетична.

3. Атактична.

4. Атонічно-астатична.

5. Змішані: а) спастико-атактична; б) спастико-гіперкінетична; в) атактикогіперкінетична [9].

Аналіз низки наукових джерел з неврології дозволив узагальнити клінічні прояви форм ДЦП, зазначених вище, та виокремити обмеження учнів $y$ їx співвідношенні $з$ іншомовними комунікативними компетентностями, що мають формуватись у ході навчання (таблиці 1 і 2).

Таблиия 1

\section{Потенційні обмеження в розвитку лінгвістичних компетентностей старшокласників, викликані ДЦП}

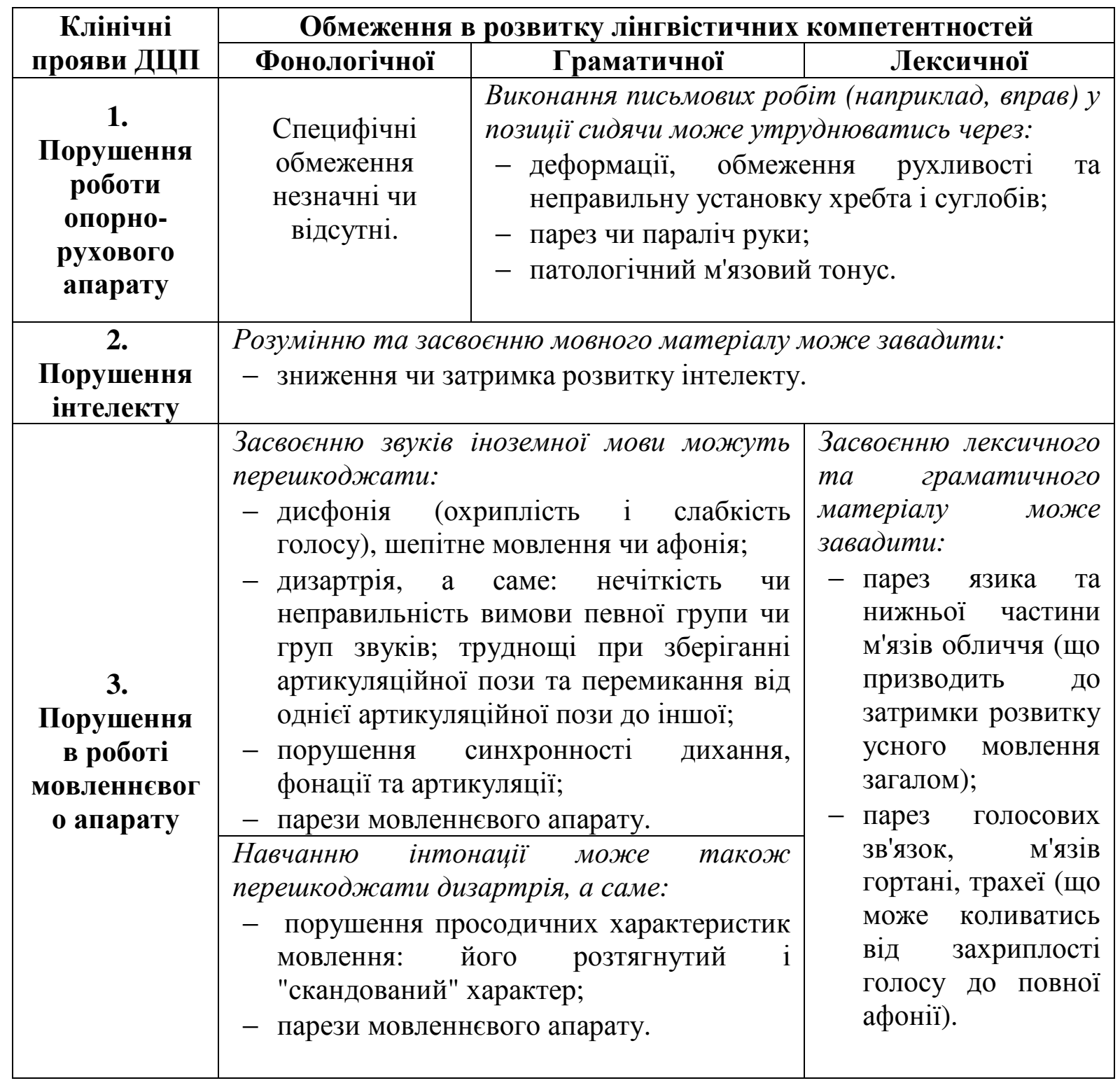




\begin{tabular}{|c|c|}
\hline $\begin{array}{l}\text { 4. } \\
\text { Порушення } \\
\text { зору }\end{array}$ & $\begin{array}{l}\text { Зоровому сприйманню матеріалу можуть перешкоджати: } \\
\text { - косоокість і параліч погляду (за яких внаслідок подвоєння } \\
\text { зображення предметів мозок поступово блокує роботу одного } \\
\text { ока, зір стає монокулярним (необ'ємним) і може далі } \\
\text { погіршуватись [37]); } \\
\text { - ністагми (які через коливальні рухи очного яблука не дозволяють } \\
\text { зосередити погляд); } \\
\text { - атрофія зорових нервів (за якої поступово погіршується гострота } \\
\text { зору, що може спричинити сліпоту). }\end{array}$ \\
\hline $\begin{array}{l}5 . \\
\text { Порушення } \\
\text { слуху }\end{array}$ & $\begin{array}{l}\text { Слуховому сприйманню мовного }(\check{u} \text { особливо фонетичного }) \\
\text { матеріалу може перешкоджати: } \\
\text { - погіршення гостроти слуху. }\end{array}$ \\
\hline $\begin{array}{c}\text { 6. Інші } \\
\text { чинники }\end{array}$ & $\begin{array}{l}\text { Навчанню можуть також заважати: } \\
\text { - епілептичні напади та судоми;синкінезії, гіперкінези та } \\
\text { інтенційний тремор;дисметрія та гіперметрія;атаксія;болі та } \\
\text { емоційні розлади, що виникають внаслідок порушень у роботі } \\
\text { організму дитини. }\end{array}$ \\
\hline
\end{tabular}

Таблиия 2

Можливі обмеження в розвитку мовленнєвих компетентностей старшокласників, викликані ДЦП

\begin{tabular}{|c|c|c|c|}
\hline \multirow{2}{*}{$\begin{array}{c}\text { Клінічні } \\
\text { прояви ДЦП }\end{array}$} & \multicolumn{3}{|c|}{ Обмеження в розвитку мовленнсвих компетенцій: } \\
\hline & $\begin{array}{c}\text { в говорінні }(\Gamma) \\
\text { / аудіюванні }(\mathbf{A})\end{array}$ & \multicolumn{2}{|l|}{$\begin{array}{l}\text { в читанні (Ч) } \\
\text { / письмі (П) }\end{array}$} \\
\hline $\begin{array}{l}\text { 1. Порушення } \\
\text { роботи опорно- } \\
\text { рухового } \\
\text { апарату }\end{array}$ & $\begin{array}{l}\text { Специфічні } \\
\text { обмеження незначні } \\
\text { чи відсутні. }\end{array}$ & \multicolumn{2}{|c|}{$\begin{array}{l}\text { Обмеження в навчанні сидячи можуть } \\
\text { бути викликані такими факторами, як: } \\
\text { - відсутність правильної установки } \\
\text { тулуба і кінцівок, деформація хребта і } \\
\text { суглобів, контрактури; } \\
\text { - параліч чи парез рук; } \\
\text { - знижений чи підвищений тонус м'язів. }\end{array}$} \\
\hline $\begin{array}{l}\text { 2. Порушення } \\
\text { інтелекту }\end{array}$ & \multicolumn{3}{|c|}{$\begin{array}{l}\text { Формуванню всіх видів мовлення можуть перешкоджати: } \\
\text { - затримка психічного розвитку; } \\
\text { - зниження інтелекту різного ступеня. }\end{array}$} \\
\hline \multirow[b]{2}{*}{$\begin{array}{l}\text { 3. Порушення в } \\
\text { роботі } \\
\text { мовленнсвого } \\
\text { апарату }\end{array}$} & \multicolumn{2}{|c|}{ Г / Ч (вголос) } & $\mathbf{A} / \boldsymbol{\Pi}$ \\
\hline & \multicolumn{2}{|c|}{$\begin{array}{l}\text { Навчанню усного мовлення та читання вголос може } \\
\text { завадити дизартрія у таких ї̈ проявах: } \\
\text { - недостатня артикуляція звуків (що призводить } \\
\text { до нерозбірливості мовлення); } \\
\text { - нескоординованість фонації, артикуляції та } \\
\text { мовленнєвого дихання; } \\
\text { - заміна "складних" звуків та їх сполучень } \\
\text { простішими для вимови; } \\
\text { - запинки на складних звукосполученнях, що } \\
\text { нагадують заїкання; } \\
\text { - порушення просодичних характеристик } \\
\text { мовлення (знижений темп, нерівний ритм, }\end{array}$} & $\begin{array}{l}\text { Специфічн } \\
\text { і } \\
\text { обмеження } \\
\text { незначні } \\
\text { чи } \\
\text { відсутні. }\end{array}$ \\
\hline
\end{tabular}




\begin{tabular}{|c|c|c|c|}
\hline & \multicolumn{2}{|c|}{$\begin{aligned} & \text { відсутні інтонації тощо); } \\
& \text { - } \text { розтягнуте "скандоване" мовлення; } \\
& \text { - } \text { уповільнене мовлення з поступовим затиханням } \\
& \text { голосу; } \\
& \text { - шепітне мовлення з придихом чи повна афонія; } \\
& \text { - салівація (слинотеча). }\end{aligned}$} & \\
\hline \multirow[b]{2}{*}{$\begin{array}{c}\text { 4. Порушення } \\
\text { зору }\end{array}$} & $\Gamma / \mathbf{A}$ & \multicolumn{2}{|l|}{$\mathbf{Y} / \Pi$} \\
\hline & $\begin{array}{l}\text { Специф. } \\
\text { обмеження } \\
\text { незначні. }\end{array}$ & \multicolumn{2}{|c|}{$\begin{array}{c}\text { Розвитку вказаних видів мовлення можуть } \\
\text { завадити: косоокість та параліч погляду; ністагми; } \\
\text { атрофія зорових нервів; зниження гостроти зору від } \\
\text { незначного до сліпоти. }\end{array}$} \\
\hline \multirow[b]{2}{*}{$\begin{array}{c}\text { 5. Порушення } \\
\text { слуху }\end{array}$} & \multicolumn{2}{|r|}{$\Gamma / \mathbf{A}$} & $\mathbf{4} / \Pi$ \\
\hline & \multicolumn{2}{|c|}{$\begin{array}{l}\text { Навчанню діалогічного мовлення та аудіювання } \\
\text { може зашкодити: } \\
\text { - погіршення гостроти слуху. }\end{array}$} & $\begin{array}{l}\text { Специфічні } \\
\text { обмеження } \\
\text { незначні. }\end{array}$ \\
\hline $\begin{array}{l}\text { 6. Інші } \\
\text { чинники }\end{array}$ & \multicolumn{3}{|c|}{$\begin{array}{l}\text { Негативно вплинути на навчальний процес можуть також: } \\
\text { - епілептичні напади та судоми, патологічні рухи, дисметрія та } \\
\text { гіперметрія, атаксія, болі та емоційні розлади. }\end{array}$} \\
\hline
\end{tabular}

На думку Л.О. Бадаляна, Л.Т. Журби й О.В. Тімоніної [9], клінічні прояви описаних форм ДЦП мають враховуватись у розробці та прогнозуванні ефективності навчального процесу. У контексті нашого дослідження це означає систематизацію та відбір електронних застосунків, що можуть використовуватись учнями з ДЦП з метою компенсації існуючих у них обмежень у вивченні IM. Врахування останніх $є$, по суті, визнанням особливих освітніх потреб учнів (табл. 3). Вказані застосунки можуть використовуватись як завдання для самостійного виконання в інклюзивній чи дистанційній іншомовній освіті, від якої звільнені учні з інтелектуальними вадами.

У таблиці 3 нами не розглядались обмеження, пов'язані з порушеннями чи затримкою інтелектуального розвитку учнів, оскільки останні в Україні звільняються від вивчення IM. Подальша систематизація електронних застосунків можлива в залежності від характеру, важкості та комбінацій клінічних проявів ДЦП в окремих учнів. Їх відбір також залежатиме від індивідуальних уподобань старшокласників, їх навчальних досягнень і матеріально-технічних можливостей школи та батьків.

Таблиця 3

Систематизація електронних застосунків, придатних для вивчення IM, y відповідності до обмежень та особливих освітніх потреб старшокласників 3 ДЦП

\begin{tabular}{|c|c|c|c|}
\hline $\begin{array}{c}\text { Компе- } \\
\text { тентно- } \\
\text { сті }\end{array}$ & $\begin{array}{c}\text { Обмеження } \\
\text { учнів з різними } \\
\text { формами ДЦП }\end{array}$ & $\begin{array}{c}\text { Їх відповідні } \\
\text { особливі освітні } \\
\text { потреби }\end{array}$ & $\begin{array}{c}\text { Електронні застосунки, що } \\
\text { реалізують особливі освітні } \\
\text { потреби, та їхні функції }\end{array}$ \\
\hline
\end{tabular}




\begin{tabular}{|c|c|c|c|c|}
\hline 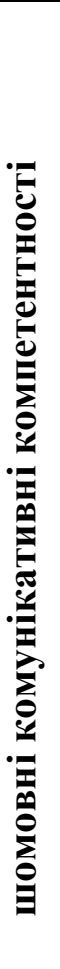 & 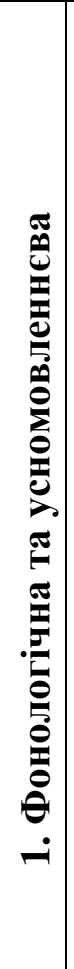 & $\begin{array}{l}\text { Tруднощзі: } \\
\checkmark \text { голосно, чітко } \\
\text { та рівно } \\
\text { говорити; } \\
\checkmark \text { правильно } \\
\text { вимовляти певні } \\
\text { звуки; } \\
\checkmark \text { переходити від } \\
\text { одного звука до } \\
\text { іншого; } \\
\checkmark \text { відтворювати } \\
\text { різницю м між } \\
\text { подібними } \\
\text { звуками; } \\
\checkmark \text { дотримуватися } \\
\text { правильної } \\
\text { інтонації, темпу } \\
\text { та } \\
\text { мовлення. }\end{array}$ & $\begin{array}{l}\text { Потреба в: } \\
\checkmark \text { додатковому } \\
\text { вправлянні у вимові } \\
\text { окремих звуків / } \\
\text { звукосполучень / слів; } \\
\checkmark \text { додатковому } \\
\text { тренуванні у } \\
\text { використанні звуків / } \\
\text { звукосполучень / слів } \\
\text { в усному мовленні; } \\
\checkmark \text { додатковій роботі } \\
\text { над інтонаційними } \\
\text { моделями ІМ, що } \\
\text { викликають триощі; вимог, } \\
\text { труднощі; } \checkmark \\
\text { щниженні висуваються до } \\
\text { учнів. }\end{array}$ & 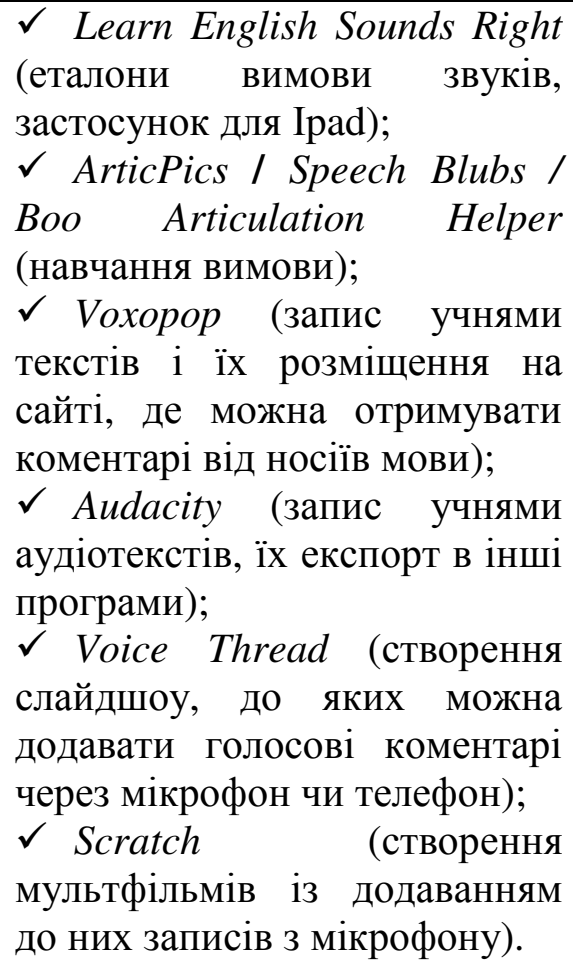 \\
\hline 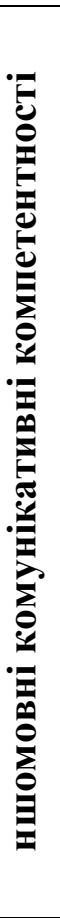 & 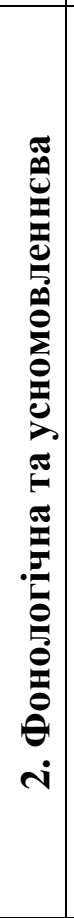 & $\begin{array}{l}\text { Неможли-вість: } \\
\checkmark \text { бачити } \\
\text { транскрип-ційні } \\
\text { знаки / слова / } \\
\text { завдання; } \\
\checkmark \text { чути звуки / } \\
\text { завдання } \\
\text { мовлення; } \\
\checkmark \text { вимовляти } \\
\text { звуки / слова / } \\
\text { речення. }\end{array}$ & 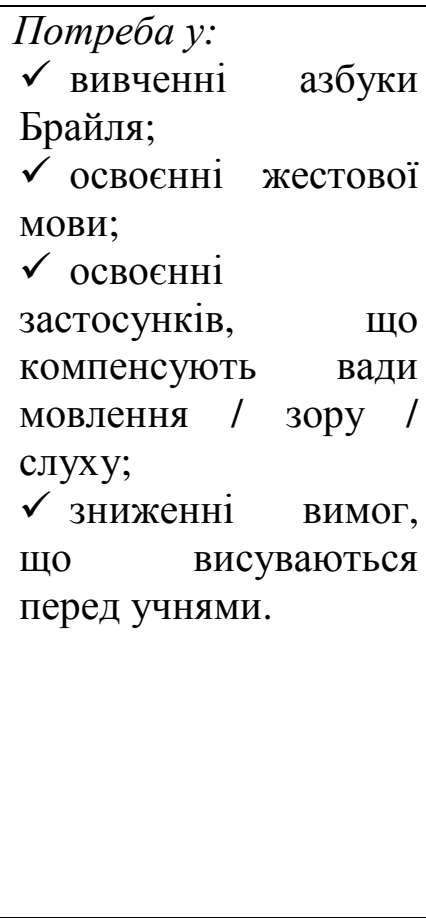 & 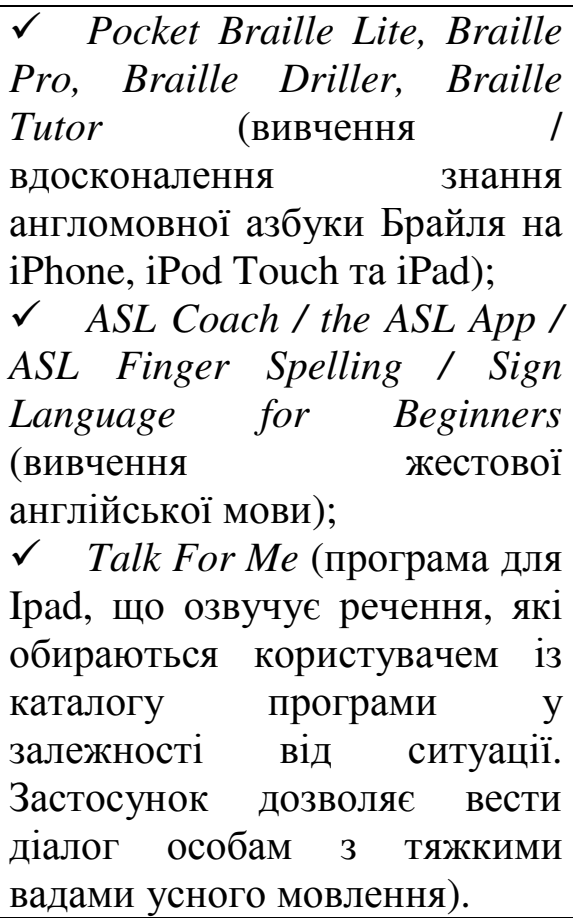 \\
\hline
\end{tabular}




\begin{tabular}{|c|c|c|c|c|}
\hline & 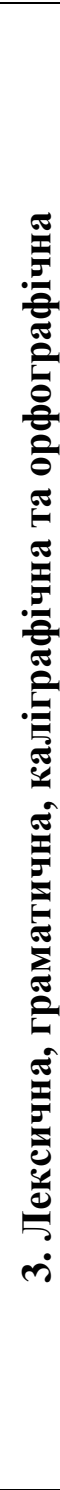 & $\begin{array}{l}\text { Tруднощзі: } \\
\checkmark \text { працював-ти, } \\
\text { стоячи біля } \\
\text { дошки / сидячи за } \\
\text { партою; } \\
\checkmark \text { писати; } \\
\checkmark \text { друкувати; } \\
\checkmark \text { виконувати } \\
\text { лексико- } \\
\text { граматичні } \\
\text { вправи в тому } \\
\text { самому обсязі / за } \\
\text { той самий час, що } \\
\text { й однолітки } 3 \\
\text { типовим } \\
\text { розвитком. }\end{array}$ & $\begin{array}{l}\text { Потреба в: } \\
\checkmark \text { спеціальній } \\
\text { організації робочого } \\
\text { місця; } \\
\checkmark \text { додатковому } \\
\text { вправлянні у техніці } \\
\text { письма (каліграфії та } \\
\text { орфографії); } \\
\checkmark \text { додатковому } \\
\text { використанні } \\
\text { матеріалу в усному та } \\
\text { писемному мовленні; } \\
\checkmark \text { застосуванні } \\
\text { комп'ютерних } \\
\text { програм, } \\
\text { дозволяють певною } \\
\text { мірою компенсувати } \\
\text { наявні вади розвитку / } \\
\text { зниженні вимог до } \\
\text { вивчення ІМ } / \\
\text { продовженні часу на } \\
\text { вивчення матеріалу. }\end{array}$ & 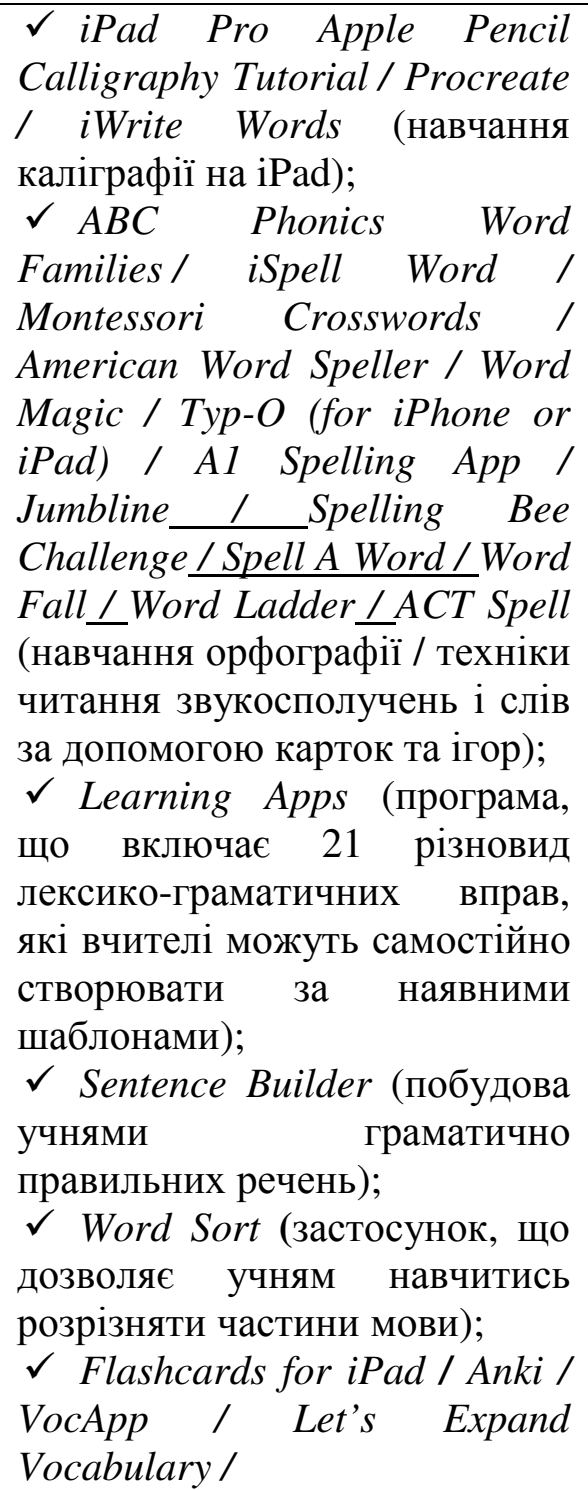 \\
\hline 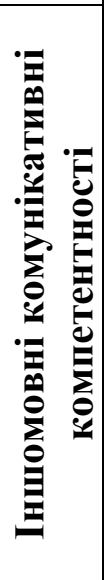 & $\dot{\theta}$ & & & 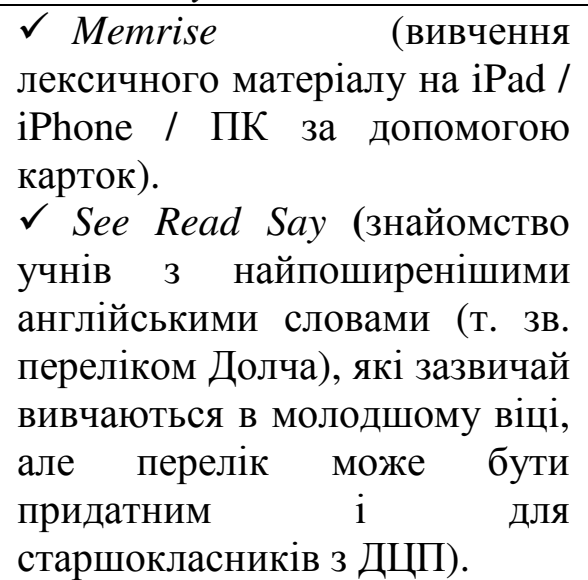 \\
\hline
\end{tabular}




\begin{tabular}{|c|c|c|c|}
\hline $\begin{array}{l}m \\
\dot{\theta} \\
\dot{\vec{n}} \\
\dot{\vec{\theta}}\end{array}$ & $\begin{array}{l}\text { Неможли-вість: } \\
\checkmark \text { бачити чи чути } \\
\text { лексико- } \\
\text { граматичний } \\
\text { матеріал у зв' язку } \\
3 \text { вадами зору / } \\
\text { слуху; } \\
\checkmark \text { писати чи } \\
\text { друкувати слова } 3 \\
\text { різних причин. }\end{array}$ & $\begin{array}{l}\text { Потреба в: } \\
\checkmark \text { застосунках, що } \\
\text { можуть компенсувати } \\
\text { наявні вади розвитку; } \\
\checkmark \text { зниженні вимог, } \\
\text { що висуваються } \\
\text { перед учнями. }\end{array}$ & $\begin{array}{l}\checkmark \text { див. застосунки 1-2 до } \\
\text { пункту } 2 \text { (Фонологічна та } \\
\text { усномовленнєва); } \\
\checkmark \text { Прилад Tobii Dynavox eуe } \\
\text { tracker } 3 \text { відповідним } \\
\text { програмним забезпеченням, } \\
\text { що, відстежуючи рухи очей, } \\
\text { дозволяє учня читати } \\
\text { потрібну інформацію з ПК. }\end{array}$ \\
\hline 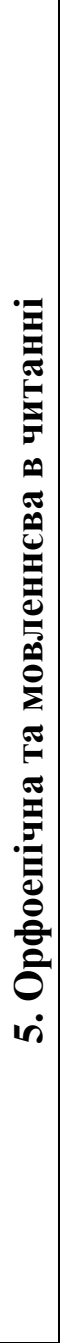 & $\begin{array}{l}\text { Tруднощзі: } \\
\checkmark \\
\text { сидячи за партою; } \\
\checkmark \text { читати вголос } \\
\text { через: } \\
\text { недостатню } \\
\text { артикуляцію } \\
\text { звуків; } \\
\text { нескоордино- } \\
\text { ваність фонації, } \\
\text { артикуляції та } \\
\text { мовленнєвого } \\
\text { дихання; заміну } \\
\text { "складних" звуків } \\
\text { та їх сполучень } \\
\text { простішими для } \\
\text { вимови; запинки } \\
\text { на складних } \\
\text { звукосполу- } \\
\text { ченнях; }\end{array}$ & $\begin{array}{l}\text { Потреба в: } \\
\checkmark \text { спеціальній } \\
\text { організації робочого } \\
\text { місця; } \\
\checkmark \text { додатковому } \\
\text { самостійному } \\
\text { вправлянні в читанні } \\
\text { вголос / про себе; } \\
\checkmark \text { використанні } \\
\text { застосунків, } \\
\text { компенсують } \\
\text { недостатню гостроту } \\
\text { зору та інші вади } \\
\text { розвитку (напр., } \\
\text { дислексію) / зниженні } \\
\text { вимог до учнів з ДЦП } \\
/ \text { продовженні часу, } \\
\text { потрібного для } \\
\text { читання. }\end{array}$ & 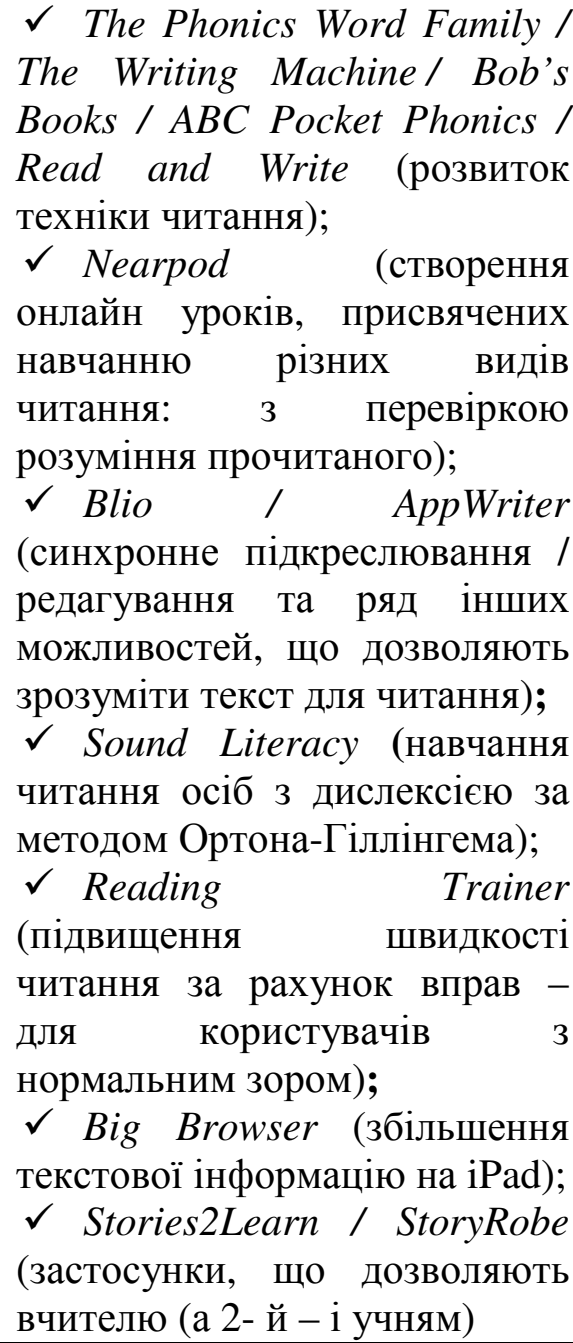 \\
\hline
\end{tabular}




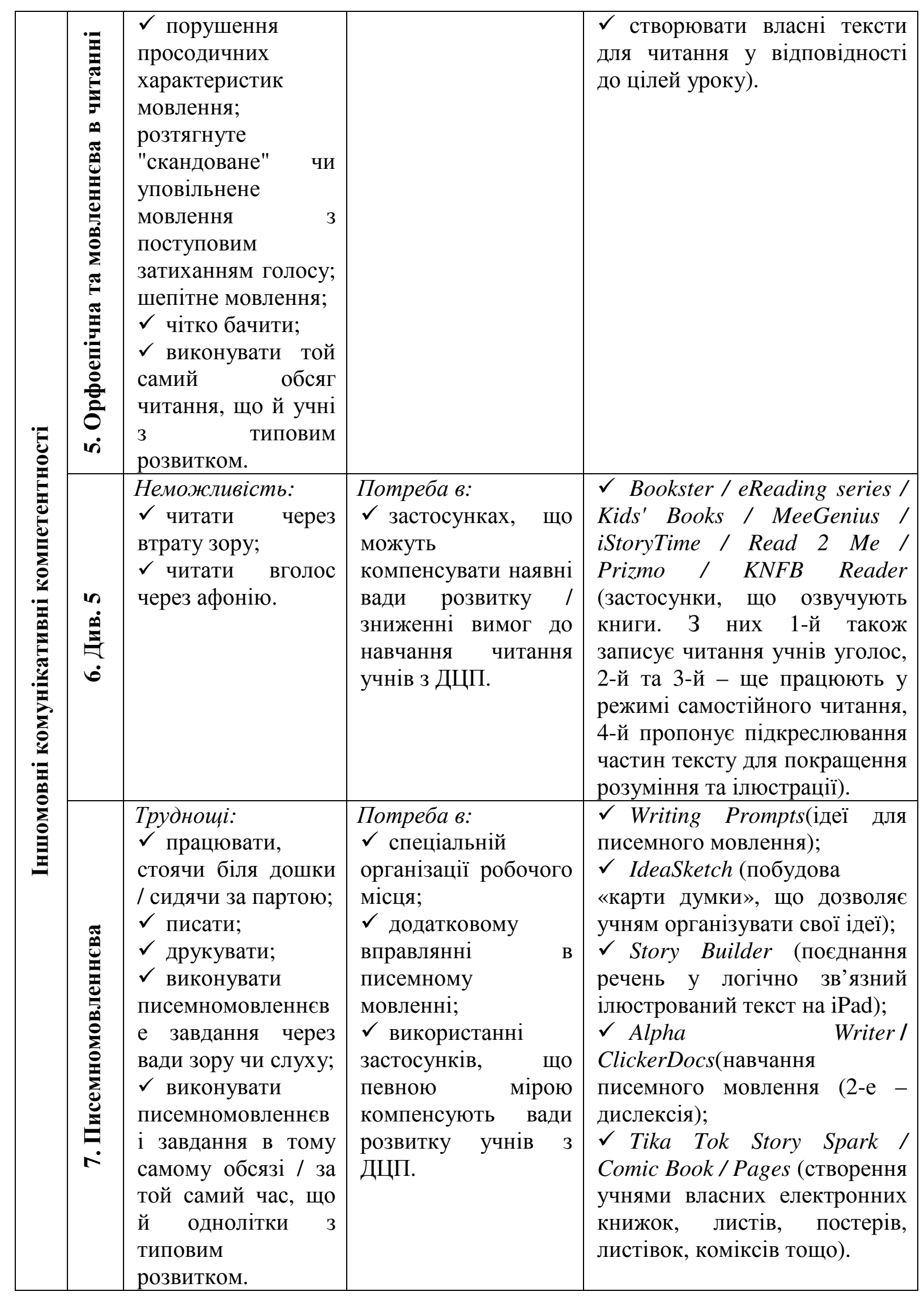




\begin{tabular}{|c|c|c|c|c|}
\hline \multirow{3}{*}{ 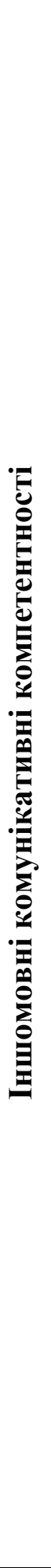 } & $\stackrel{\sim}{\stackrel{0}{a}}$ & $\begin{array}{l}\text { Неможливість: } \\
\checkmark \text { бачити; } \\
\checkmark \text { писати; } \\
\checkmark \text { друкувати } \\
\text { загалом } \\
\text { користуватись } \\
\text { руками; }\end{array}$ & $\begin{array}{l}\text { Потреба в: } \\
\text { застосунках, що } \\
\text { можуть } \\
\text { компенсувати наявні } \\
\text { вади розвитку / } \\
\text { зниженні вимог до } \\
\text { навчальних } \\
\text { досягнень учнів } \\
\text { ДЦП. }\end{array}$ & $\begin{array}{l}\text { Dragon } \\
\text { (застосунок, що трансформує } \\
\text { усний текст у письмовий. Це } \\
\text { компенсує неможливість } \\
\text { писати та допомагає засвоїти } \\
\text { орфографію іноземної мови); } \\
\checkmark \text { Braille Pad / The M Braille } \\
\text { app / The Visual Brailler } \\
\text { (застосунки, що дозволяють } \\
\text { учням писати та редагувати } \\
\text { смс, повідомлення в } \\
\text { соціальних мережах і тексти } \\
\text { швидше, використовуючи } \\
\text { англомовну азбуку Брайля). }\end{array}$ \\
\hline & 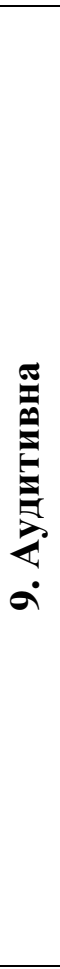 & $\begin{array}{l}\text { Tруднощі: } \\
\checkmark \text { правильно } \\
\text { зрозуміти } \\
\text { аудіотекст через } \\
\text { вади слуху; } \\
\checkmark \text { розвинути } \\
\text { аудитивні вміння } \\
\text { за той самий час і в } \\
\text { тому самому } \\
\text { обсязі, що й } \\
\text { однолітки } \\
\text { типовим } \\
\text { розвитком. }\end{array}$ & $\begin{array}{l}\text { Потреба в: } \\
\checkmark \text { додаткових } \\
\text { заняттях, } \\
\text { спрямованих на } \\
\text { навчання } \\
\text { аудіювання; } \\
\checkmark \text { застосунках, що } \\
\text { можуть певним } \\
\text { чином компенсувати } \\
\text { вади слуху. }\end{array}$ & $\begin{array}{l}\checkmark \text { Stories2Learn / StoryRobe } \\
\text { (застосунки, що дозволяють } \\
\text { вчителю і учням записувати } \\
\text { власні аудіотексти потрібної } \\
\text { тематики і складності); } \\
\checkmark \text { Play Posit (застосунок, що } \\
\text { дозволяє вчителю "нарізати" } \\
\text { відео і додавати до нього } \\
\text { завдання / запитання на } \\
\text { розуміння прослуханого); } \\
\checkmark \text { Аидасіty (застосунок для } \\
\text { запису, редагування та } \\
\text { експорту аудіофайлів: } \\
\text { наприклад, текстів для } \\
\text { аудіювання, диктантів); } \\
\checkmark \text { Му Tоurs (створення } \\
\text { інтерактивних віртуальних } \\
\text { екскурсій за участі голосу, } \\
\text { карт і фото для ПК } \\
\text { мобільних пристроїв). }\end{array}$ \\
\hline & $\begin{array}{l}\dot{\rho} \\
\dot{\theta} \\
\dot{\theta}\end{array}$ & $\begin{array}{l}\text { Неможсливість: } \\
\checkmark \text { розуміти } \\
\text { аудіотекст на слух } \\
\text { через глухоту. }\end{array}$ & $\begin{array}{l}\text { Потреба в: } \\
\checkmark \text { застосунках, що } \\
\text { можуть певним } \\
\text { чином компенсувати } \\
\text { глухоту; } \\
\checkmark \text { зниженні вимог } \\
\text { до учнів. }\end{array}$ & $\begin{array}{l}\checkmark \text { My Subtitle (додавання } \\
\text { субтитрів до відео). }\end{array}$ \\
\hline
\end{tabular}

\section{3. ВИСНОВКИ ТА ПЕРСПЕКТИВИ ПОДАЛЬШИХ ДОСЛІДЖЕНЬ}

Розглянута вище систематизація електронних застосунків є спробою висвітлити надзвичайно широку проблему підвищення якості іншомовної освіти старшокласників з ДЦП засобами IКТ. У даному випадку доцільно оцінити стан конкретної дитини та вибрати стратегію адаптації чи модифікації навчального процесу. У першому випадку перед дослідниками розкриваються перспективи подальших наукових розвідок щодо 
компенсації різноманітних комплексних порушень засобами підбору відповідних електронних застосунків.

\title{
СПИСОК ВИКОРИСТАНИХ ДЖЕРЕЛ
}

[1] The Council of Europe. The Committee of Ministers. (2006, Apr. 5). Recommendation Rec (2006)6 on the Council of Europe Action Plan to promote the rights and full participation of people with disabilities in society: improving the quality of life of people with disabilities in Europe 2006-2015 [Електронний pecypc]. Доступно: https://rm.coe.int/CoERMPublicCommonSearchServices/DisplayDCTMContent?documentId=09000016 80595206.

[2] ООН. (1994, июл. 7-19). Саламанкская декларация и рамки действий по образованию лии с особыми потребностями, принятые Всемирной конференцией по образованию лии с особыми потребностями: доступ $u$ качество. [Електронний ресурс]. Доступно: http://www.un.org/ru/documents/decl_conv/declarations/pdf/salamanka.pdf.

[3] Соціальна інтеграція дитини-інваліда в Україні: концепція, завдання, перспективи. [Електронний pecypc]. Доступно: http://nmcpto.sumy.ua/wp-content/uploads/2013/10/1.pdf. Дата звернення: Черв. 9, 2018.

[4] ООН. (1981, нояб. 7). Сандбергская декларация. [Електронний ресурс]. Доступно:: http://www.un.org/ru/documents/decl_conv/declarations/sundberg.shtml.

[5] Верховна Рада України (2017, вер. 28). Закон Украӥни "Про загальну середню освіту". [Електронний ресурс]. Доступно: http://zakon0.rada.gov.ua/laws/show/651-14.

[6] Прикладне програмне забезпечення. Система тестування [Електронний ресурс]. Доступно: http://kn.esy.es/uncategorized. Дата звернення: Cер. 5, 2018.

[7] Метод Козявкина. Реабилитация пациентов, страдающих детским церебральным параличом - ДЦП [Електронний ресурс]. Доступно: http://www.reha.lviv.ua/game-basedrehabilitation.98.html?\&no_cache=1\&L=1. Дата обращения: Авг 7, 2018.

[8] В. І. Козявкін та ін, Метод Козявкіна - система інтенсивної нейрофізіологічної реабілітації. Посібник реабілітолога. Львів,Україна: Дизайн-студія "Папуга", 2011.

[9] Л. О. Бадалян, Л. Т. Журба, та О. В. Тимонина, Детские иеребральные параличи. Киев,Украина: Здоровье, 1988.

Матеріал надійшов до редакиії 19.08..2018

\section{ИСПОЛЬЗОВАНИЕ ЭЛЕКТРОННЫХ ПРИЛОЖЕНИЙ В ИЗУЧЕНИИ ИНОСТРАННОГО ЯЗЫКА СТАРШЕКЛАССНИКАМИ С ДЕТСКИМ ЦЕРЕБРАЛЬНЫМ ПАРАЛИЧОМ}

\author{
Наталия Сергеевна Щерба \\ кандидат педагогических наук, доцент, \\ доцент кафедры межкультурной коммуникации и прикладной лингвистики \\ Житомирский государственный университет имени Ивана Франко, г. Житомир, Украина \\ ORCID ID 0000-0002-5467-4292 \\ scherbanatasha@gmail.com
}

\begin{abstract}
Аннотация. Статья посвящена актуальной проблеме повышения эффективности обучения иностранному языку старшеклассников с детским церебральным параличом за счет отбора и систематизации электронных приложений.

В соответствии с Законом Украины «Об общем среднем образовании» ученики с особенными образовательными потребностями могут обучаться в общеобразовательных школах (в частности, в специальных / инклюзивных классах или по дистанционной / вечерней / заочной форме обучения), а также в специальных школах (для детей, нуждающихся в коррекции физического и / или умственного развития), к которым принадлежат и учебно-реабилитационные центры (для детей, нуждающихся в систематической реабилитации вследствие сложных нарушений развития). Внедрение Социальной модели инвалидности, начатое в Украине, предполагает постепенный отказ от сегрегации детей с инвалидностью в специальных учебных заведениях. Это означает
\end{abstract}


максимальную компенсацию их ограничений в инклюзивном учебном процессе благодаря его адаптации (или, в отдельных случаях, модификации) к их особенным образовательным потребностям. Определенным потенциалом в этом контексте обладают электронные приложения, которые понимаются в статье как пользовательские компьютерные программы, позволяющие решать конкретные прикладные задачи пользователя.

Преследуя цель статьи, автор классифицирует электронные приложения по критериям: места их функционирования (на размещенные в Интернете на специально созданных платформах / требующие загрузки на компьютер); сферы применения (на приложения общего и специального назначения). Приложения специального назначения, которые могут использоваться в иноязычном образовании, предлагается классифицировать в зависимости от компетентностей, для развития которых они используются. Систематизированные таким образом приложения отобраны в соответствии с особенными образовательными потребностями старшеклассников с детским церебральным параличом. Полученные результаты исследования сформулированы в виде таблиц.

Ключевые слова: иностранный язык; старшеклассники; ДЦП; электронное приложение.

\title{
USING WEB APPLICATIONS IN TEACHING FOREIGN LANGUAGES TO UPPER SECONDARY SCHOOL STUDENTS WITH CEREBRAL PALSY
}

\author{
Nataliia S. Shcherba \\ $\mathrm{PhD}$ of Pedagogical Sciences, \\ Associate Professor, the Chair for Intercultural Communication and Applied Linguistics \\ Zhytomyr Ivan Franko State University, Zhytomyr, Ukraine \\ ORCID ID 0000-0002-5467-4292 \\ scherbanatasha@gmail.com
}

\begin{abstract}
The article is dedicated to a highly topical issue of raising the effectiveness of teaching upper secondary school students with cerebral palsy foreign languages by means of the selection and classification of web applications.

According to the Law of Ukraine «On General Secondary Education», SEND (special educational needs and disabilities) students can study in mainstream schools (and namely, in special / inclusive classes or in distant / evening / extramural educational settings), and also in special schools (meant for children who need special education due to their physical impairments or mental disability), among which there are also education-and-rehabilitation centers (for children who need regular rehabilitation because of the complexity of their impairments). The implementation of the Social model of disability, started in Ukraine, presupposes the gradual transition from segregation to inclusion of SEND children. It can be implemented by means of numerous adjustments in mainstream educational settings so that all the barriers are removed, unless the modification of learning is viewed as the best choice. Some of the adjustments mentioned can be introduced by means of web-applications interpreted in this research as users' computer programs that empower them to solve certain tasks.

Pursuing the aim of the article the author classifies web applications by the following criteria: their location (on a special web platform or on a user's personal computer); the field of usage (whether they are supposed to be applied by general public or in a special field only). The latter include applications, designed for teaching foreign language. These are classified according to the competencies that they enable to develop (namely, language and speech ones). Finally, the web applications are grouped according to barriers and special educational needs typical for upper secondary school students with cerebral palsy. The results obtained are generalized in tables suggested.
\end{abstract}

Keywords: foreign language; upper secondary school student; cerebral palsy; web application.

\section{REFERENCES (TRANSLATED AND TRANSLITERATED)}

[1] The Council of Europe. The Committee of Ministers. (2006, Apr. 5). Recommendation Rec (2006)6 on the Council of Europe Action Plan to promote the rights and full participation of people with disabilities in society: improving the quality of life of people with disabilities in Europe 2006-2015 [online]. Available: https://rm.coe.int/CoERMPublicCommonSearchServices/DisplayDCTMContent?documentId=09000016 
80595206 (in English)

[2] UNO. (1994, Jun 7-19) The Salamanca Statement and Framework for Action on Special Needs Education [online]. Available: http://www.un.org/ru/documents/decl_conv/declarations/pdf/salamanka.pdf (in Russian).

[3] The social integration of children with disabilities in Ukraine: the concept, tasks and prospects for futureю [online]. Available: http://nmcpto.sumy.ua/wp-content/uploads/2013/10/1.pdf. Accessed on: May 9, 2018 (in Ukrainian).

[4] UNO. (1981, Nov. 7) Sandberg Declaration. [online]. Available: http://www.un.org/ru/ documents/decl_conv/declarations/sundberg.shtml (in Russian).

[5] The Supreme Council of Ukraine ( 2017, Sep. 28) Law of Ukraine "On general secondary education" [online]. Available: http://zakon0.rada.gov.ua/laws/show/651-14 (in Ukrainian).

[6] Applied Software. The system of testing [online]. Available: http://kn.esy.es/uncategorized. Accessed on: Aug. 5, 2018 (in Ukrainian).

[7] Koziavkin method. Rehabilitation of palsied patients [online]. Available: http://www.reha.lviv.ua/gamebased-rehabilitation.98.html?\&no_cache=1\&L=1. Accessed on: Aug 7, 2018 (in Russian).

[8] V. I. Koziavkin et al., Koziavkin method - a system of intensive neurophysiological rehabilitation. A manual of a rehabilitation specialist. Lviv, Ukraine: Dyzain-studiia "Papuga", 2011 (in Ukrainian).

[9] L.O. Badalian, L.T. Zhurba, and O.V. Timonina, Cerebral palsies. Kyiv, Ukraine: Zdorovye, 1988 (in Russian).

\section{(cc) BY-NC-SA}

This work is licensed under Creative Commons Attribution-NonCommercial-ShareAlike 4.0 International License. 